MENDONÇA, RM; VIEIRA, EA; FIALHO, JF; RIBEIRO, MR; SENE, JCS; PAIVA, WM; MALAQUIAS, JV. 2020. Agronomic performance of sweet cassava cultivars. Horticultura Brasileira 38: 434-438. DOI: http://dx.doi.org/10.1590/s0102-0536202004015

\title{
Agronomic performance of sweet cassava cultivars
}

\section{Ricardo M de Mendonça ${ }^{1} \mathbb{D}$; Eduardo A Vieira ${ }^{2} \mathbb{D}$; Josefino de F Fialho ${ }^{2} \mathbb{D}$; Marcos R Ribeiro ${ }^{1} \mathbb{D}$; José Carlos da $S$ Sene ${ }^{2} \mathbb{D}$; Weslley $M$ de Paiva ${ }^{1} \mathbb{D}$; Juaci Vitória Malaquias ${ }^{2} \mathbb{D}$}

'Faculdades Associadas de Uberaba (FAZU), Uberaba-MG, Brasil; ricardo@fazu.br; marcos-ricarte@hotmail.com; weslley.paiva10@ hotmail.com; ㄹmbrapa Cerrados, Brasília-DF, Brasil; eduardo.alano@embrapa.br; josefino.fialho@embrapa.br; jose.egn.sene@hotmail. com; juaci.malaquias@embrapa.br

\begin{abstract}
Brazilian sweet cassava consumers are becoming more and more demanding in relation to sanitary conditions, organoleptic and nutritional characteristics of this vegetable products and their derivatives. Thus, more nutritious, early, productive, adapted to mechanized planting and good culinary quality sweet cassava cultivars were developed. This study aimed, therefore, to evaluate the performance of four sweet cassava cultivars in Uberaba, in Triângulo Mineiro region. The experiments were carried out in the experimental field of Faculdades Associadas de Uberaba (FAZU) during two harvest seasons. We adopted a randomized block design with three replicates, each plot consisting of four lines with ten plants. Trait averages were grouped by the Scott \& Knott test. The results showed that cultivars BRS 399, BRS 397 and IAC 576-70 have potential to be grown in the region, since they showed root yield higher than $32 \mathrm{tha}^{-1}$ and up to 30-minute cooking time. BRS 399 stood out for its performance, showing root yield of $37 \mathrm{tha}^{-1}$ and $48 \mathrm{t} \mathrm{ha}^{-1}$ in 2015/2016 and 2016/2017 harvest seasons, respectively, with short-time cooking and presenting shoot productivities which allow its use even as animal feed.
\end{abstract}

Keywords: Manihot esculenta, aipim, macaxeira, root yield, culinary qualities.

\section{RESUMO}

\section{Desempenho agronômico de cultivares de mandioca de mesa}

Os consumidores brasileiros de mandioca de mesa estão se tornando mais exigentes quanto aos aspectos sanitários, organolépticos e nutricionais dos produtos e derivados de mandioca que adquirem. Em resposta, foram desenvolvidas cultivares de mandioca de mesa, mais nutritivas, precoces, produtivas, adaptadas ao plantio mecanizado e com boas qualidades culinárias. Nesse cenário, oportunizou-se a presente pesquisa, cujo objetivo foi avaliar o desempenho de quatro novas cultivares de mandioca de mesa em Uberaba na região do Triângulo Mineiro. Os experimentos foram conduzidos no campo experimental das Faculdades Associadas de Uberaba (FAZU) durante duas safras. Foi utilizado o delineamento de blocos casualizados com três repetições, cada parcela composta por quatro linhas com dez plantas. As médias dos caracteres foram agrupadas por meio do teste de Scott \& Knott. Os resultados revelaram que as cultivares BRS 399, BRS 397 e IAC 576-70 têm potencial para cultivo na região, uma vez que apresentaram produtividade de raízes superior a $32 \mathrm{t} \mathrm{ha}^{-1}$ e tempo para o cozimento de até 30 minutos. A BRS 399 se destacou pelo desempenho apresentado, com produtividade de raízes de $37 \mathrm{t} \mathrm{ha}^{-1}$ e $48 \mathrm{t} \mathrm{ha}^{-1}$ nas safras 2015/2016 e 2016/2017, respectivamente, com baixos tempos para o cozimento e com produtividades de parte aérea que permitem utilizar a mesma até na alimentação animal.

Palavras-chave: Manihot esculenta, aipim, macaxeira, produtividade de raízes, qualidades culinárias.

\section{Received on February 13, 2020; accepted on September 18, 2020}

$\mathrm{C}$ assava customers in Brazil are becoming more demanding concerning hygienic-sanitary quality (Rinaldi et al., 2015a, 2019), organoleptic (Oliveira \& Moraes, 2009; Vieira et al., 2018) and nutritional (Silva et al., 2014; Fuhrmann et al., 2019; Vieira et al., 2019) characteristics of the vegetable products and their derivatives.

The change in customer profile made, in a short period of time, cassava producers incorporate growing modern technologies (Fialho \& Vieira, 2013). Nowadays, the main producers who serve the market are horticulturists who integrate the cultivation of this species with that of various vegetables such as tomatoes, carrots, peppers, sweet potatoes, broccoli, among others.

This change in consumption patterns and cassava production occurred in parallel with innovative research on production systems, post-harvest and breeding program for cassava (Fukuda et al., 2002; Fialho \& Vieira, 2013; Vieira et al., 2013; Rinaldi et al., 2015b).

Some information about the production in Brazilian Savannah, biome in which the Triângulo Mineiro is inserted, was generated and updated, concerning choice and preparation of the area, soil conservation techniques, liming, fertilization, gypsum 
application, selection and prepare of planting material, planting systems, planting times, spacing and planting density, intercropping, crop rotation, weed control, shoot pruning, harvest, pest control, disease control, among others (Fialho \& Vieira, 2013). The research also developed, for the Brazilian Savannah biome, an irrigation management which takes into account the daily soil water balance, to determine the ideal moment for irrigation and the amount of water applied in cassava crop (Antonini et al., 2017).

Regarding post-harvesting, strategies to maximize useful life of the roots submitted to minimum processing and frozen (Rinaldi et al., 2015a, b, 2017) and different packing systems (Rinaldi et al., 2019) were developed. In the last years, more nutritive, early, productive, adapted to mechanized planting and with good cooking quality cassava cultivars were developed for the Brazilian Savannah conditions, in special for Distrito Federal Region (Vieira et al., 2011, 2018, 2019).

However, despite the edaphoclimatic conditions and market potential of Triângulo Mineiro region for cassava cultivation (Fialho \& Vieira, 2013), systematic studies on agronomic cassava cultivars in the region are still scarce in literature, and there is no cultivar recommended for this environment.

Thus, this study aimed to evaluate the agronomic performance of four cassava cultivars in the municipality of Uberaba-MG, in Triângulo Mineiro region.

\section{MATERIAL AND METHODS}

The experiments were carried out during two harvest seasons in the experimental field of the school-farm at Faculdades Associadas de Uberaba (FAZU), in Uberaba-MG (19\%44'45"S, 47057'415"W, $771 \mathrm{~m}$ altitude), from August, 2015, to May, 2016, and from August, 2016, to May, 2017. The soil was classified as Red-Yellow Latosol, medium texture (Embrapa, 2018) and, according to Köppen-Geiger, the local climate is Aw (tropical with dry season). During the experiment,
2015/2016 and 2016/2017 harvests, the weather variables were measured and soil physicochemical composition was determined (Table 1).

Four sweet cassava cultivars were selected, to be grown in Distrito Federal, BRS 399, BRS 397, BRS Moura and IAC 575-70 (Fialho et al., 2009; Vieira et al., 2015, 2018), with still no reported information on agronomic performance in Uberaba-MG in Triângulo Mineiro region, though.

The experimental design was randomized blocks, with three replicates, being each plot composed of four lines with 10 plants. The spacing used was $0.80 \mathrm{~m}$ between plants and $1.00 \mathrm{~m}$ between rows, each plot consisted of 16 central plants. The selection of propagating material and fertilization followed the recommendations for cassava cultivation in the Brazilian Savannah region (Fialho \& Vieira, 2013). The experiments were conducted under conventional sprinkler irrigation up to the beginning of rainy season, based on the daily soil water balance at the effective depth of the cassava root system $(0.40 \mathrm{~m})$, according to the management proposed by Antonini et al. (2017).

At harvest, five agronomic traits were evaluated: i) plant height in meters $(\mathrm{PH})$; ii) shoot weight without original stem cutting in $\mathrm{kg} \mathrm{ha}^{-1}$ (ShW); and iii) root yield in $\mathrm{kg} \mathrm{ha}^{-1}(\mathrm{RY})$; iv) percentage of starch content in roots using the hydrostatic balance method (RSC), described by Grosmann \& Freitas (1950); and v) cooking time in minutes (CT), according to the method described by Borges et al. (2002).

The obtained data were submitted to variance analysis according to randomized block design, following the model: $Y i j k=m+G i+B k+A j+G A i j+$ Eijk, in which: Yijk = observed value of genotype $\mathrm{i}$ in block $\mathrm{k}$ from environment $\mathrm{j} ; \mathrm{m}=$ general average; $\mathrm{Gi}=$ effect of genotype $\mathrm{i} ; \mathrm{Bk}=$ effect of block $\mathrm{k}$; $\mathrm{Aj}$ $=$ effect of the environment; GAij = effect of the interaction of genotype i with environment $\mathrm{j}$; Eijk = experimental error. In order to analyze hypothesis of data normality, Shapiro-Wilk's test at 5\% probability was used (Shapiro \& Wilk, 1965). Trait averages were grouped using Scott \& Knott's agglomerative test at 5\% probability of error (Scott \& Knott, 1974). Statistical analyses were performed using Softwares R (R Core Team, 2019) and Genes (Cruz, 2016).

\section{RESULTS AND DISCUSSION}

Shapiro-Wilk's test showed that the residues for the traits evaluated in the experiment presented normal distribution at $5 \%$ probability of error and they can be evaluated using parametric tests (Table 2). The coefficients of variation of the variance analyses ranged from $7.02 \%$ for starch content in roots (RSP) to $11.18 \%$ for root yield (RY), showing good experimental accuracy (Ferreira, 1991).

The variance analysis showed significant differences between the average harvests, 2015/2016 (S1) and 2016/2017 (S2), for shoot weight without original stem cutting (ShW), root yield (RY) and cooking time (CT) (Table2). This result indicates the influence of the year in phenotypic manifestation of these traits and it is in accordance with what was widely reported in literature (Vieira et al., 2009, 2015, 2019; Silva et al., 2014). The influence of the year can be explained by weather variations, such as, rainfall, maximum and minimum temperatures, wind speed, insolation, solar radiation, among others (Silva et al., 2017).

Significant differences among averages of cultivars for all evaluated traits were verified (Table 2). This variation can be explained by the genetic variability verified in the group of the evaluated cultivars (Vieira et al., 2011, 2018; Fuhrmann et al., 2019), which probably shows that the sweet cassava cultivars chosen to be tested in this study were suitable.

The presence of significant interaction between crop and cultivar factors for PH, ShW, RY and CT (Tables 2 and 3) showed differential behavior of cultivars in each harvest. This result is similar to the one reported for sweet cassava in Brazilian Savannah biome by Fialho et al. (2009), Silva et al. (2014), Vieira et al. (2015) and Fuhrmann et al. (2019). 
Among the evaluated cultivars, the ones which showed higher values for plant height (PH) in 2015/2016 harvest were BRS 397 and BRS 399 and in 2016/2017 harvest were BRS 399 and IAC 576-70 (Table 3). Higher averages for $\mathrm{PH}$ are important for recommending cultivars for cultivation due to: i) it facilitates cultural practices (weeding, field inspections and pesticide applications); ii) for greater availability of stem cuttings and iii) to facilitate mechanized planting. The superiority of cultivar BRS 399 for PH had already been reported by Vieira et al. (2018) in a study carried out during three harvests in 18 locations in Federal District and surroundings and by Fuhrmann et al. (2019) in a study carried out during two harvests in Planaltina-DF.

For shoot weight ( $\mathrm{ShW}$ ) in 2015/2016 harvest, cultivar BRS 397 was the one which showed superior average when compared with the others, $26.83 \mathrm{t} \mathrm{ha}^{-1}$, whereas cultivar BRS 399 showed superior average in 2016/2017 harvest, $26.46 \mathrm{t} \mathrm{ha}^{-1}$ (Table 3). This trait is important when selecting a cultivar, since it is related to the possibility of using cassava shoot as protein source for

Table 1. Weather variables and soil physico-chemical composition, in 2015/2016 and 2016/2017 harvests in Uberaba (MG). Uberaba, FAZU/Embrapa, 2019.

\begin{tabular}{lcc}
\hline \multirow{2}{*}{ Weather variables } & \multicolumn{2}{c}{ Harvest } \\
\cline { 2 - 3 } & $\mathbf{2 0 1 5} / \mathbf{2 0 1 6}$ & $\mathbf{2 0 1 6} / \mathbf{2 0 1 7}$ \\
\hline Maximum daily temperature $\left({ }^{\circ} \mathrm{C}\right)$ & 31.63 & 30.68 \\
Average daily minimum temperatures $\left({ }^{\circ} \mathrm{C}\right)$ & 19.37 & 17.66 \\
Average daily temperature $\left({ }^{\circ} \mathrm{C}\right)$ & 24.59 & 23.73 \\
Average relative humidity $(\%)$ & 70.15 & 63.50 \\
Accumulated rainfall $(\mathrm{mm})$ & 1462 & 1703 \\
Soil pH in $\mathrm{H}_{2} \mathrm{O}$ & 6.0 & 6.2 \\
Ca & 2.1 & 2.1 \\
Mg in soil $\left(\mathrm{cmolc}^{++}\right.$in soil $\left(\mathrm{cmolc}^{-3}\right)$ & 0.6 & 0.5 \\
Phosphorus in soil $\left(\mathrm{mg} \mathrm{dm}^{-3}\right)$ & 24 & 30 \\
Potassium in soil $\left(\mathrm{mg} \mathrm{dm}^{-3}\right)$ & 72 & 65 \\
Organic matter in soil $\left(\mathrm{g} \mathrm{kg}^{-1}\right)$ & 28 & 30 \\
Clay in soil $\left(\mathrm{g} \mathrm{kg}^{-1}\right)$ & 300 & 210 \\
Sand in soil $\left(\mathrm{g} \mathrm{kg}^{-1}\right)$ & 550 & 600 \\
Silt in soil $(\mathrm{g} \mathrm{kg})$ & 150 & 190 \\
\hline
\end{tabular}

animal feed (Fernandes et al., 2016) and, greater soil cover efficiency (erosion control, soil humidity maintenance and weed control). We highlight that in the study carried out by Fuhrmann et al. (2019) both cultivars showed average ShW of $20 \mathrm{t} \mathrm{ha}^{-1}$, whereas in the experiments conducted by Vieira et al. (2018) these cultivars showed ShW higher than $30 \mathrm{t} \mathrm{ha}^{-1}$.

All cultivars showed averages similar for percentage of starch content in roots (RSC) in 2015/2016 harvest, whereas, in 2016/2017 harvest, the cultivars BRS Moura, IAC 756-70 and BRS 397 showed similar averages of root starch content (RSC) among each other and superior averages in relation to cultivar BRS 399 (Table 3). Although being important for the use of roots in the production of flour and starch, this trait presents a secondary importance considering sweet cassava breeding program. RSC shows importance only when the goal is the use of roots for dual-purpose (in natura and industry), when, for example: the goal is to produce yellow cassava flour. Lower percentages of starch in roots of cultivar BRS 399 comparing with cultivars BRS 397 and IAC 576-70 had already been reported by Fuhrmann et al. (2019) in a study carried out during two harvests in Planaltina-DF, in which the cultivar showed RSC of 22.96 and $24.83 \%$ in harvests at 11 months after planting, rainfed conditions.

No significant differences were

Table 2. Summary of the variance analysis and variation coefficient (CV\%) of the plant height in meters (PH), shoot weight without original stem cutting in $\mathrm{kg} \mathrm{ha}^{-1}(\mathrm{ShW})$, root yield in $\mathrm{kg} \mathrm{ha}^{-1}(\mathrm{RY})$, percentage of starch in roots (RSC) and cooking time in minutes (CT), evaluated in four sweet cassava cultivars, in 2015/2016 (S1) and 2016/2017 (S2) harvests in Uberaba (MG). Uberaba, FAZU/Embrapa, 2019.

\begin{tabular}{|c|c|c|c|c|c|c|}
\hline \multirow{2}{*}{ Variation source } & \multirow{2}{*}{$\begin{array}{l}\text { Degrees of } \\
\text { freedom }\end{array}$} & \multicolumn{4}{|c|}{ Medium square } & \multirow[b]{2}{*}{ CT } \\
\hline & & PH & ShW & RY & RSC & \\
\hline Harvests (S) & 1 & 0.001 & $22504067^{*}$ & $426094401^{*}$ & 2 & $876^{*}$ \\
\hline Cultivars (C) & 3 & $0.834^{*}$ & $265088381^{*}$ & $287385673^{*}$ & $27^{*}$ & $69^{*}$ \\
\hline $\mathrm{C} \times \mathrm{S}$ & 3 & $0.503^{*}$ & $308943558^{*}$ & $389483148^{*}$ & 4 & $17^{*}$ \\
\hline Residues (R) & 14 & 0.038 & 4191811 & 14961821 & 4 & 2 \\
\hline Total & 23 & - & - & - & - & - \\
\hline Average & & 2.56 & 22906 & 34604 & 30.21 & 16.79 \\
\hline $\mathrm{p}-\mathrm{SW}^{* *}$ & & 0.47 & 0.98 & 0.61 & 0.83 & 0.59 \\
\hline CV (\%) & & 7.58 & 8.94 & 11.18 & 7.02 & 8.58 \\
\hline
\end{tabular}

*significant at $5 \%$ error probability by $\mathrm{F}$ test. ${ }^{* *}$ Shapiro Wilk's test with error probability. 
Table 3. Comparison of averages of plant height in meters (PH), shoot weight without original stem cutting in $\mathrm{kg} \mathrm{ha}^{-1}$ (ShW), root yeld in $\mathrm{kg} \mathrm{ha}^{-1}(\mathrm{RY})$, starch content in roots in percentage (RSC) and cooking time in minutes (CT), evaluated in four sweet cassava cultivars, in 2015/2016 (S1) and 2016/2017 (S2) harvests in Uberaba (MG). Uberaba, FAZU/Embrapa, 2019.

\begin{tabular}{|c|c|c|c|c|c|c|c|c|c|c|}
\hline \multirow{2}{*}{ Cultivars } & \multicolumn{2}{|c|}{ PH } & \multicolumn{2}{|c|}{ ShW } & \multicolumn{2}{|c|}{ RY } & \multicolumn{2}{|c|}{ RSC } & \multicolumn{2}{|c|}{ CT } \\
\hline & S1 & $\mathbf{S 2}$ & S1 & $\mathbf{S 2}$ & S1 & $\mathbf{S 2}$ & S1 & S2 & S1 & S2 \\
\hline IAC 576-70 & $2.46 \mathrm{Bb}$ & $2.99 \mathrm{Aa}$ & $22584 \mathrm{Bb}$ & $26465 \mathrm{Ab}$ & $41896 \mathrm{Aa}$ & $31219 \mathrm{Bb}$ & $30.82 \mathrm{Aa}$ & $30.93 \mathrm{Aa}$ & $20 \mathrm{Ab}$ & $11 \mathrm{Ba}$ \\
\hline BRS 397 & $2.86 \mathrm{Aa}$ & $2.30 \mathrm{Bb}$ & $26833 \mathrm{Aa}$ & $12600 \mathrm{Bc}$ & $34854 \mathrm{Aa}$ & $29153 \mathrm{Ab}$ & $30.41 \mathrm{Aa}$ & $30.22 \mathrm{Aa}$ & $19 \mathrm{Ab}$ & $8 \mathrm{Bb}$ \\
\hline BRS 399 & $2.67 \mathrm{Ba}$ & $3.11 \mathrm{Aa}$ & $23563 \mathrm{Bb}$ & $39215 \mathrm{Aa}$ & $37625 \mathrm{Ba}$ & $48535 \mathrm{Aa}$ & $28.66 \mathrm{Aa}$ & $25.93 \mathrm{Ab}$ & $30 \mathrm{Aa}$ & $13 \mathrm{Ba}$ \\
\hline BRS Moura & $2.26 \mathrm{Ab}$ & $1.80 \mathrm{Bc}$ & $22517 \mathrm{Ab}$ & $9469 \mathrm{Bc}$ & $40896 \mathrm{Aa}$ & $12656 \mathrm{Bc}$ & $31.98 \mathrm{Aa}$ & $32.74 \mathrm{Aa}$ & $22 \mathrm{Ab}$ & $11 \mathrm{Ba}$ \\
\hline
\end{tabular}

*means followed by the same uppercase letters in the rows and lowercase letters in the columns do not differ by Scott \& Knott test ( $>0.05$ ) error probality.

noticed between RY averages of cultivars in 2015/2016 harvests: all of them showed averages higher than 34 $t$ ha $^{-1}$. In 2016/2017 harvest, cultivar BRS 399 showed statistically superior average of RY when comparing with the others $\left(48.53 \mathrm{t} \mathrm{ha}^{-1}\right)$, whereas the cultivars IAC 576-70 (31.896 $\left.\mathrm{t} \mathrm{ha}^{-1}\right)$ and BRS 397 (29.15 $\left.\mathrm{t} \mathrm{ha}^{-1}\right)$ showed averages which were statistically equal among them, superior to the cultivar BRS Moura (12.66 tha ${ }^{-1}$ ), tough (Table 3). The average RY of cultivar BRS 399, in the two harvests were $43 \mathrm{t} \mathrm{ha}^{-1}$, when compared with the RY averages of the best sweet cassava genotypes, reported in other studies $55 \mathrm{t} \mathrm{ha}^{-1}$ (Fialho et al., 2009), $53 \mathrm{t} \mathrm{ha}^{-1}$ (Vieira et al., 2009), $24 \mathrm{t}$ ha $^{-1}$ (Vieira et al., 2011) $26 \mathrm{t} \mathrm{ha}^{-1}$ (Silva et al., 2014), 44 t ha ${ }^{-1}$ (Vieira et al., 2015), $41 \mathrm{t} \mathrm{ha}^{-1}$ (Vieira et al., 2018) and $35 \mathrm{t}$ ha $^{-1}$ (Fuhrmann et al., 2019), showed the high potential of this sweet cassava cultivar in Uberaba-MG.

In the group of the evaluated cultivars, all of them showed up to 30-minute CT (Table 3), which is an indispensable factor for the commercialization of cassava roots for culinary use (Fukuda et al., 2002). Both in 2015/2016 and in 2016/2017 harvests, cultivar BRS 397 showed CT lower than cultivar BRS 399, which indicates that all the evaluated cultivars showed high culinary quality, being excellent to be commercialized.

The results obtained in this study showed that all evaluated cultivars, except BRS Moura, showed potential for cultivation in Uberaba-MG, since: i) showed averages of RY higher than $32 \mathrm{t} \mathrm{ha}^{-1}$, which is an optimal RY for Brazilian Savannah conditions in
Central Brazil (Vieira et al., 2018); ii) presented averages of $\mathrm{CT}$ of up to 30 minutes, within the acceptable limit for the commercialization of sweet cassava (Fukuda et al., 2002); iii) showed average $\mathrm{PH}$ of $2.73 \mathrm{~m}$, which is considered a good height for cassava plants (Vieira et al., 2018); and iv) presented ShW higher than $19 \mathrm{t} \mathrm{ha}^{-1}$, which is considered a good forage yield, as cassava shoot area showed an average of $13 \%$ of crude protein (Fernandes et al., 2016).

The fact that more than one cultivar stood out is important because it contributes to the maintenance of genetic variability under cultivation. However, we highlight that cultivar BR 399 stood out comparing with the others, in relation to agronomic performance, $\mathrm{RY}$ of $37.62 \mathrm{t} \mathrm{ha}^{-1}$ and $48.53 \mathrm{tha}^{-1}$ in 2015/2016 and 2016/2017 harvests, respectively, with CT within acceptable limits for the commercialization and shoot yield which allow the producer to use the surplus production as animal feed.

However, before recommending any of the evaluated cultivars for commercial planting in Triângulo Mineiro region, it would be interesting to validate their performance in a greater number of locations, using the methodology of participatory selection of cassava cultivars (Fialho \& Vieira, 2011), in which, in addition to agronomic data, information related to producers' preferences would be studied.

\section{ACKNOWLEDGEMENTS}

The authors thank to Faculdades
Associadas de Uberaba (FAZU), to Brazilian Agricultural Research Corporation (Embrapa), to Foundation for research support of Minas Gerais (FAPEMIG), to Brazil Bank Foundation (FBB) and to The National Council for Scientific and Technological Development (CNPq) for financial support.

\section{REFERENCES}

ANTONINI, JCA; FIALHO, JF; SOUSA, DMG; VIEIRA, EA. 2017. Irrigação. In: FIALHO, JF; VIEIRA, EA; BORGES, AL (eds). Cultivo da mandioca para região do Brazilian Savannah. Brasília: Embrapa Cerrados. p. 24-26.

BORGES, MF; FUKUDA, WMG; ROSSETTI, AG. 2002. Avaliação de variedades de mandioca para consumo humano. Pesquisa Agropecuária Brasileira 37: 1559-1565.

CRUZ, CD. Genes Software - extended and integrated with the R, Matlab and Selegen. 2016. Acta Scientiarum 38: 547-552.

EMBRAPA - Empresa Brasileira de Pesquisa Agropecuária. 2018. Sistema brasileiro de classificação de solos. Brasília: Embrapa, $356 \mathrm{p}$.

FERNANDES, FD; GUIMARÃES JÚNIOR, R; VIEIRA, EA; FIALHO, JF; MALAQUIAS, JV. Produtividade e valor nutricional da parte aérea e de raízes tuberosas de oito genótipos de mandioca de indústria. 2016. Revista Brasileira de Saúde e de Produção Animal 17: 1-12.

FERREIRA, PV. 1991 Estatística experimental aplicada à agronomia. Maceió: EDUFAL. $437 \mathrm{p}$.

FIALHO, JF; VIEIRA, EA. 2011. Seleção participativa de variedades de mandioca na agricultura familiar. Brasília: Embrapa Cerrados. 76p.

FIALHO, JF; VIEIRA, EA. 2013. Mandioca no Cerrado Brasileiro: orientações técnicas. 2.ed. Brasília: Embrapa Cerrados. 203p.

FIALHO, JF; VIEIRA, EA; SILVA, MS; PAULA-MORAES, SV; FUKUDA, WMG; SANTOS FILHO, MOS; SILVA, KN. 2009. 
Desempenho de variedades de mandioca de mesa no Distrito Federal. Revista Brasileira Agrociência 15: 31-35.

FUHRMANN, E; VIEIRA, EA; FIALHO JF, FALEIRO, FG; CARVALHO, LJCB. 2019. Agronomic performance and biochemical attributes of yellow-pulped elite sweet cassava clones. Cientifica 47: 77-82.

FUKUDA, WMG; SILVA, SO; IGLESIAS, C. 2002. Cassava breeding. Crop Breeding and Applied Biotechnology 2: 617-638.

GROSMANN, J; FREITAS, AG. 1950. Determinação do teor de matéria seca pelo método do peso específico em raízes de mandioca. Revista Agronômica 14: 75-80.

OLIVEIRA, MA; MORAES, PSB. 2009. Características físico-químicas, cozimento e produtividade de mandioca cultivar IAC 57670 em diferentes épocas de colheita. Ciência e Agrotecnologia 33: 837-843.

R Core Team. R: A language and environment for statistical computing. Vienna: R Foundation for Statistical Computing, 2019.

RINALDI, MM; VIEIRA, EA; FIALHO, JF. 2015a. Conservaação pós-colheita de diferentes cultivares de mandioca submetidas ao processamento mínimo e congelamento Científica 43: 287-301.

RINALDI, MM; VIEIRA, EA; FIALHO, JF. 2019. Postharvest conservation of minimally processed cassava roots subjected to different packaging systems. Cientifica 47: 144-155.

RINALDI, MM; VIEIRA, EA; FIALHO, JF; MALAQUIAS, JV. 2015b. Efeito de diferentes formas de congelamento sobre raízes de mandioca de mesa. Brazilian Journal of Food Technology 18: 93-101.

RINALDI, MM; VIEIRA, EA; FIALHO, JF; MALAQUIAS, JV. 2017. Shelf life of minimally processed cassava roots submitted to different conservation methods. Cientifica 45: 9-17.

SCOTT, AJ; KNOTT, MA. 1974. A cluster analysis method for grouping means in the analysis of variance. Biometrics 30: 507-512.

SHAPIRO, SS; WILK, MB. 1965. An analysis of variance test for normality (complete samples). Biometrika 52: 591-611.

SILVA, FAM; FIALHO, JF; CORREIA, JR; VIEIRA, EA. 2017. Aspectos edafoclimáticos. In: FIALHO, JF; VIEIRA, EA; BORGES, $\mathrm{AL}$ (eds). Cultivo da mandioca para região do Cerrado Brasileiro. Brasília: Embrapa Cerrados. p.08-15.

SILVA, KN; VIEIRA, EA; FIALHO, JF; CARVALHO, LJCB; SILVA, MS. 2014. Potencial agronômico e teor de carotenoides em raízes de reserva de mandioca. Ciência Rural 44: 1348-1354.

VIEIRA, EA; FIALHO, JF; CARVALHO, LJCB; MALAQUIAS, JV; FERNANDES, FD. 2015. Desempenho agronômico de acessos de mandioca de mesa em área de Cerrado Brasileiro no município de Unaí, região noroeste de Minas Gerais. Cientifica 43: 371-377.

VIEIRA, EA; FIALHO, JF; FALEIRO, FG; BELLON, G; FONSECA, KG; CARVALHO,
LJCB; SILVA, MS; MORAES, SVP; OLIVEIRA, CM; DENKE, ML. 2011. Characterization of sweet cassava accessions based on molecular, quantitative and qualitative data. Crop Breeding and Applied Biotechnology 11: 232-240.

VIEIRA, EA; FIALHO, JF; JULIO, L; CARVALHO, LJCB; DALLA CORTE, JL; RINALDI, MM; OLIVEIRA, CM; FERNANDES, FD; ANJOS, JRN. 2018. Sweet cassava cultivars with yellow or cream root pulp developed by participatory breeding. Crop Breeding and Applied Biotechnology 18: 450-454.

VIEIRA, EA; FIALHO, JF; JULIO, L; CARVALHO, LJCB; DALLA CORTE, JL; RINALDI, MM; OLIVEIRA, CM; FERNANDES, FD; ANJOS, JRN. 2019. BRS 400 e BRS 401, sweet cassava cultivars with pink roots developed by participatory breeding. Crop Breeding and Applied Biotechnology 19: 501-504.

VIEIRA, EA; FIALHO, JF; SILVA, MS. 2013. Recursos genéticos e melhoramento da mandioca. In: FIALHO, JF; VIEIRA, EA (eds). Mandioca no Cerrado Brasileiro: Orientações Técnicas. 2.ed. Brasília: Embrapa Cerradoss. p. 27-37.

VIEIRA, EA; FIALHO, JF; SILVA, MS; FUKUDA, WMG; SANTOS FILHO, MOS. 2009. Comportamento de genótipos de mandioca de mesa no Distrito Federal. Revista Ciência Agronômica 40: 113-122. 